\title{
Early melt season snowpack isotopic evolution in the Tarfala valley, northern Sweden
}

\author{
Helen E. DAHLKE, ${ }^{1}$ Steve W. LYON ${ }^{1,2}$ \\ ${ }^{1}$ Department of Physical Geography and Quaternary Geology, Stockholm University, Stockholm, Sweden \\ E-mail: helen.dahlke@natgeo.su.se \\ ${ }^{2}$ Bert Bolin Centre for Climate Research, Stockholm University, Stockholm, Sweden
}

\begin{abstract}
This study investigated the stable water isotopic $\left(\delta^{18} \mathrm{O}\right.$ and $\left.\delta \mathrm{D}\right)$ evolution of two snowpacks located at the same elevation on a north-facing $(\mathrm{Nf})$ and a south-facing $(\mathrm{Sf})$ slope within the Tarfala research catchment, northern Sweden, and the potential impact of pre-freshet snowpack melt on streamflow. Our results indicate that over the study period the Sf snowpack showed a more enriched isotopic composition, especially in the top of the profile, and contributed more snowmelt to streamflow than the $\mathrm{Nf}$ slope. The $\mathrm{Sf}$ snowpack also showed a significantly higher variability in snowpack $\delta^{18} \mathrm{O}$ levels and snowpack snow water equivalent (SWE) over time. Comparing snowpack and snowmelt isotopic values it was seen that the Sf slope experienced earlier snowmelt from upslope positions due to greater insolation that subsequently enhanced the meltwater flux at the base of downslope snowpacks. In contrast, the $\mathrm{Nf}$ slope primarily underwent changes within the snowpack and experienced relatively minimal melt. Detailed field-based isotopic snowmelt studies such as this highlight the potential importance of incorporating spatio-temporal runoff generation concepts into distributed energybalance models, which could allow for more accurate prediction with regard to the spatio-temporal dynamics associated with the snowmelt ion pulse.
\end{abstract}

\section{INTRODUCTION}

The time elapsed between when water enters and exits a hydrologic catchment (often considered the transit time of the water; McDonnell and others, 2010, and references therein) affects a range of activities from microbial processes (Murphy and Ginn, 2000) to biogeochemical cycling (Scanlon and others, 2001). Further, such a catchment-scale transit time is influenced by both the characteristics and the climatic setting of the catchment itself (e.g. Hrachowitz and others, 2010; Lyon and others, 2010). For example at a specific location with uniform geology and climate, the slope and aspect of the land surface will exert a strong control over the amount of received energy and will potentially influence the transit time (Broxton and others, 2009) and the hydrologic response (Lyon and others, 2009). This is especially true in snow-dominated systems found within high-latitude high-altitude landscapes where the sun is lower on the horizon, which results in a greater contrast between the energy inputs of north- and south-facing slopes.

Snow processes are inherently coupled to the land surface slope and aspect, as the amount of incoming solar radiation affects the sensible and latent heat storage of the ground and/or the snowpack (Gustafson and others, 2010), the metamorphic processes within the snowpack (e.g. Veatch and others, 2009), the redistribution of snow with wind, the timing and intensity of snowmelt (Pomeroy and others, 2003; López-Moreno and Latron, 2008) and thus the amount of snow that is accumulated in the landscape (Marsh and other, 2012). The ability to characterize the variability and influence of aspect on snow water equivalent (SWE) and snowpack chemical composition in high-elevation seasonally snow-covered basins is important both for water resources (as snowmelt water can account for a large percentage of recharge; Liu and others, 2008) and for evaluation of the hydrologic and hydrochemical response of high-elevation catchments (Kattelmann and Elder, 1991;
Gustafson and others, 2010). Additionally, the loss of snow cover is a key trigger to terrestrial and aquatic biota (e.g. Monson and others, 2006) through its role as an insulator controlling processes such as soil respiration and carbon sequestration. Field studies investigating such variability in snowpack height, SWE and isotopic composition are becoming more common (e.g. Rodhe, 1998; Taylor and others, 2001; Gustafson and others, 2010; Lee and others, 2010); however, only a few such studies coincide with hydrologic catchments where detailed observations of cryosphere interactions have been made over long periods of time such that the resulting snowpack evolution and variability can be explicitly incorporated into, and used to test, existing catchment-scale conceptualizations and process-based understanding.

In this study, we present an initial characterization of snowpack density, SWE and isotopic variability with respect to aspect differences for the Tarfala research catchment in northern Sweden. We use a short (but detailed) series of observations to develop a first attempt at a conceptualization of aspect-driven pre-freshet hydrologic response in this catchment relevant for many high-latitude high-altitude landscapes. Seasonal snow-cover and snowpack evolution play a unique role in high-altitude catchment hydrochemistry, as a snowpack tends to accrue chemicals through wet and dry deposition over the snow accumulation season and rapidly releases them during melt (Pomeroy and others, 2005) via the snowmelt ion pulse (Bales and others, 1989; Cragin and others, 1996; Harrington and Bales, 1998). Thus, this observation series allows investigation of how the snowpack isotopic profile forms during the pre-freshet period and influences stream isotopic composition. Such pre-freshet snowpack isotopic evolution sets the stage for the resultant snowmelt pulse associated with spring freshet. The results have further implications for interpretations of catchment-scale shifts in hydrology seen both in the 


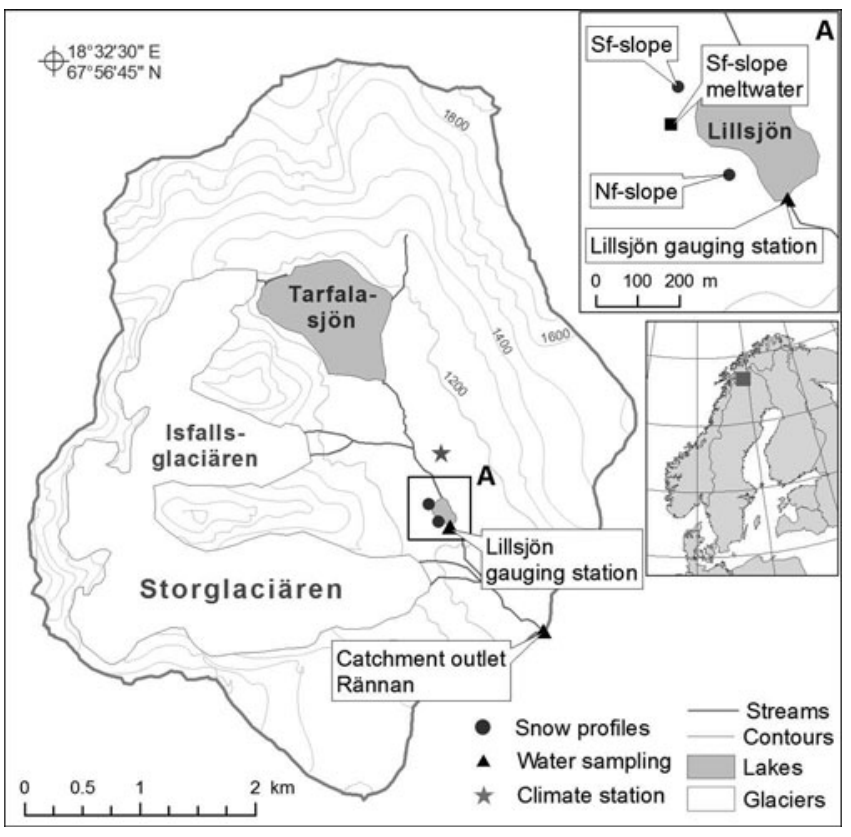

Fig. 1. Location of the Tarfala research catchment in northern Sweden, the climate station (near Tarfala research station), gauging stations (Lillsjön and Rännan), snow profiles ( $\mathrm{Sf}$ and $\mathrm{Nf}$ slope) and meltwater sampling sites ( $\mathrm{Sf}$ slope meltwater).

long-term records of observations and with ongoing hydrologic tracer experiments in Tarfala research catchment.

\section{METHODS}

\section{Study site}

This study was performed in the $21.7 \mathrm{~km}^{2}$ Tarfala catchment (outlet at $67^{\circ} 53^{\prime} 56^{\prime \prime} \mathrm{N}, 18^{\circ} 37^{\prime} 57^{\prime \prime} \mathrm{E}$ ), which is located east of the highest mountain in Sweden, Kebnekaise $(2097 \mathrm{~m}$ a.s.I.; Fig. 1). The Tarfala catchment is characterized by high gradients and steep topography with an average slope angle of $21^{\circ}$ and a local relief ranging from 980 to $2097 \mathrm{~m}$ a.s.l. The catchment is located in the discontinuous permafrost zone and is characterized by alpine heath vegetation in the valley bottom where patches of organic soils of shallow depth $(\sim 5-10 \mathrm{~cm})$ mantle the bedrock and glacial tills. Currently, about $30 \%$ of the catchment area is covered by glaciers, of which Storglaciären $\left(2.9 \mathrm{~km}^{2}\right)$ offers continuous mass-balance measurements since 1946 (Holmlund and others, 2005). The hydrologic regime in the catchment is dominated by snow and glacier melt during the summer period (i.e. June-September). The long-term average day for the onset of snowmelt is 11 June based on the period 19692011. The regional climate in northern Sweden is cold and humid. Annual variability in temperature and precipitation is generally influenced by local topography and dominant weather patterns. The mean annual air temperature recorded at the Tarfala research station (TRS; $67^{\circ} 55^{\prime} \mathrm{N}, 18^{\circ} 37^{\prime} \mathrm{E}$; $1135 \mathrm{~m}$ a.s.I.) for the period $1965-2009$ is $-3.4^{\circ} \mathrm{C}$. The mean annual precipitation measured at the TRS has been estimated as $1997 \pm 450 \mathrm{~mm}$, of which $\sim 400-600 \mathrm{~mm}$ falls between June and August (Dahlke and others, 2012).

\section{Snow and isotopic sampling}

In May 2011 seven consecutive snow cores (one every 2-3 days between 7 May and 22 May) were taken on both a north-facing $(\mathrm{Nf})$ and a south-facing ( $\mathrm{Sf}$ ) slope at the base of the glacial moraines surrounding lake Lillsjön in the Tarfala catchment near the TRS (Fig. 1). The two sites have a slope of $2^{\circ}$ (Nf slope) and $3^{\circ}$ ( $\mathrm{Sf}$ slope) and an approximate slope length of 50 and $90 \mathrm{~m}$, respectively. The snow cores were taken in approximately the same position (within $1 \mathrm{~m}$ at each site) and elevation (1120 m a.s.I.) using an $8 \mathrm{~cm}$ diameter Ice Drilling and Design Office (IDDO) snow corer. The retrieved snow cores were broken up into $15-25 \mathrm{~cm}$ long segments, with the interval depending on the stratigraphy of the snowpack. Each segment was bagged hermetically in plastic bags until laboratory analysis on the same day at the TRS. The snow density, $\rho_{\mathrm{s}}\left(\mathrm{kg} \mathrm{m}^{-3}\right)$, and the SWE $(\mathrm{cm})$ were estimated based on the volume and weight of each core segment.

In addition to these segment measures of the snowpack physical characteristics, the snow-core segment samples were analyzed for stable water isotopic composition. Using oxygen or hydrogen isotopes of meltwater, streamwater and groundwater allows estimation of the contribution of snowmelt to freshet discharge through an isotopic hydrograph separation. During snowmelt the new water input typically used for hydrograph separation should be the meltwater exiting the base of the snowpack (Rodhe, 1998). The isotopic composition of meltwater is usually assumed to be the average composition of the snowpack, which is often obtained by melting a snow core (Rodhe, 1998; Taylor and others, 2001). However, as the snowpack becomes isothermal during the snowmelt period, the diurnal melt-freeze cycles result in an isotope exchange between the ice and meltwater in the snowpack, which leads to an isotopic enrichment of the meltwater contributed to streamflow (Taylor and others, 2002). Thus, knowledge of the spatiotemporal variation of the snowpack and snowmelt isotopic composition is needed to reduce uncertainties in meltwater contributions to streamflow estimated through isotope hydrograph separations.

Snow samples were melted slowly in sealed plastic bags at $4{ }^{\circ} \mathrm{C}$ at the TRS and the resulting snowmelt water was then bottled in $50 \mathrm{~mL}$ high-density polyethylene (HDPE) bottles with Polyseal caps until laboratory analysis at Stockholm University. To complement the snow-core isotopic samples, grab samples of streamwater were collected daily at the catchment outlet (i.e. Rännan) and at the Lillsjön gauging station at approximately 17:30 local time using $60 \mathrm{~mL}$ HDPE bottles (Fig. 1). In addition, at the same time as the snow coring on the $\mathrm{Sf}$ slope, a meltwater sample was collected at the base of the Sf slope $\sim 5 \mathrm{~m}$ below the coring location. All samples (both melted snow-core samples and liquid water grab samples) were kept refrigerated until laboratory analysis for stable water isotopes at Stockholm University. Samples were analyzed for their ${ }^{18} \mathrm{O} /{ }^{16} \mathrm{O}$ ratio and ${ }^{2} \mathrm{H} /{ }^{1} \mathrm{H}$ content (expressed as $\delta^{18} \mathrm{O}$ and $\delta \mathrm{D}$ ) using a laser absorption spectrometer (Liquid-Water Isotope Analyzer DLT-100, Los Gatos Research Inc., Mountain View, CA, USA) with a precision of $0.15 \%$ and $0.6 \%$ for $\delta^{18} \mathrm{O}$ and $\delta \mathrm{D}$, respectively. These $\delta^{18} \mathrm{O}$ and $\delta \mathrm{D}$ contents are reported in \%o relative to Vienna Standard Mean Ocean Water (VSMOW). Weighted mean $\delta^{18} \mathrm{O}$ and $\delta \mathrm{D}$ values were calculated for each of the snow profiles. Values of SWE were determined for each core segment and multiplied by the observed isotopic concentrations. For each snow profile these products were integrated over the entire snowpack profile and divided by the total SWE of the snow profile to give a weighted average value (Unnikrishna and others, 2002). 


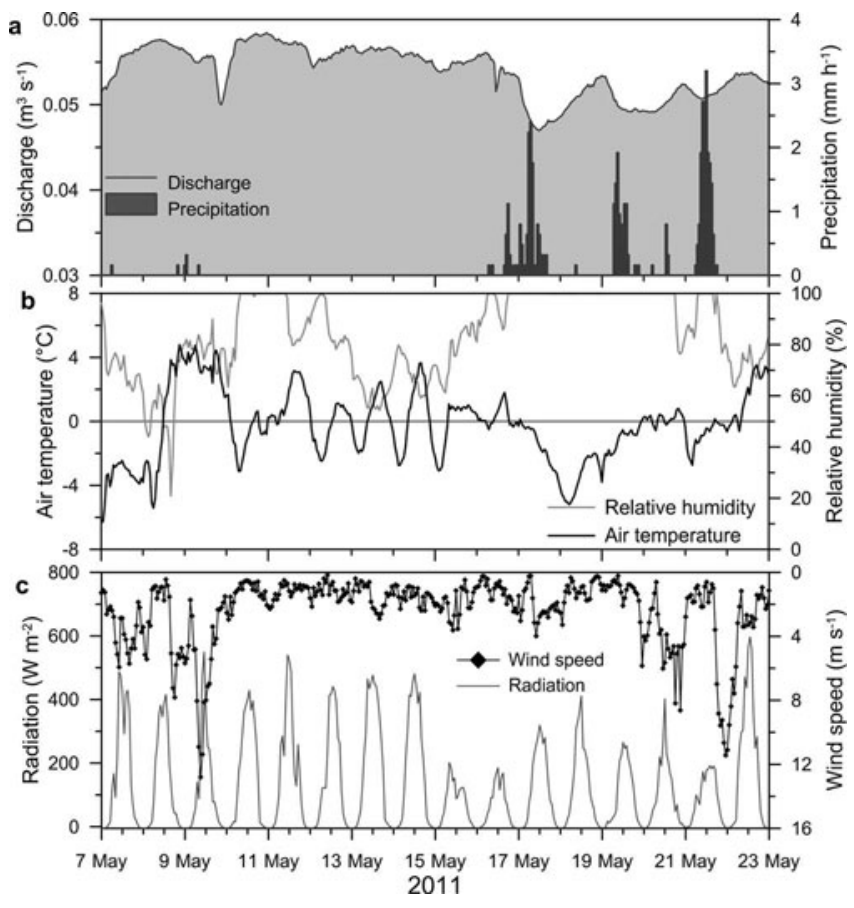

Fig. 2. (a) Hourly precipitation (grey bars) measured at the TRS and discharge measured at the outlet (Rännan) of Tarfala catchment. (b) Hourly ventilated air temperature (black line) and relative humidity (grey line) and (c) hourly global solar radiation (grey line) and wind speed (diamonds) measured at the TRS climate station for the study period 7-22 May 2011. The horizontal line in (b) highlights the $0^{\circ} \mathrm{C}$ temperature.

\section{Additional hydrometric and meteorological data}

For the study period, discharge and meteorological data were available at $10 \mathrm{~min}$ resolution. Discharge was monitored at the outlet of Tarfala catchment at Rännan $\left(67^{\circ} 53^{\prime} 56^{\prime \prime} \mathrm{N}\right.$, $18^{\circ} 37^{\prime} 57^{\prime \prime} \mathrm{E}$ ) by means of a pressure transducer (unvented
Onset $^{\mathrm{TM}} \mathrm{U} 20,9 \mathrm{~m} \pm 0.5 \mathrm{~cm}$, Bourne, MA, USA) and a stagedischarge rating curve. Meteorological variables such as precipitation, average ventilated air temperature, relative humidity, wind speed and average global radiation were recorded at the Tarfala climate station $\left(67^{\circ} 54^{\prime} 44^{\prime \prime} \mathrm{N}\right.$, $\left.18^{\circ} 36^{\prime} 46^{\prime \prime} \mathrm{E}\right)$ located near the TRS at $1135 \mathrm{~m}$ a.s.I.

\section{RESULTS AND DISCUSSION}

The study period of May 2011 was characterized by precipitation, discharge, air temperature, relative humidity, wind speed and average global radiation conditions shown in Figure 2. During the period 7-22 May 2011 a total of $45 \mathrm{~mm}$ of precipitation was recorded. Most of this precipitation fell as snow in three events after 16 May 2011. Daily minimum, maximum and mean air temperatures for this period were $-6.3^{\circ} \mathrm{C}, 4.8^{\circ} \mathrm{C}$ and $-0.6^{\circ} \mathrm{C}$, respectively. Daily temperatures were above $0^{\circ} \mathrm{C}$ mainly during the first half of the study period. In response to this increase in temperature, discharge was slightly above the mean value for the study period of $0.05 \mathrm{~m}^{3} \mathrm{~s}^{-1}$. The average maximum daily global radiation from 7 May through 22 May 2011 was $382 \mathrm{~W} \mathrm{~m}^{-2}$.

\section{Snowpack physical characteristics}

Figure 3 shows the variability in $\rho_{\mathrm{s}}$ and SWE for both the Nf and Sf snowpack from 7 May to 22 May 2011. Table 1 summarizes the daily average snowpack density and total SWE for both the $\mathrm{Nf}$ and Sf snowpack. At the beginning of the study period both the Nf and Sf snowpack showed little variation in $\rho_{\mathrm{s}}$ with depth. Despite having a greater snow depth $(255 \mathrm{~cm}$ on 7 May 2011) the Sf snowpack showed a lower average $\rho_{\mathrm{s}}$ of $383 \pm 13 \mathrm{~kg} \mathrm{~m}^{-3}$ at the beginning of the study period than the shallower $\mathrm{Nf}$ snowpack $(190 \mathrm{~cm}$ on 7 May 2011), which had an average $\rho_{\mathrm{s}}$ of $418 \pm 72 \mathrm{~kg} \mathrm{~m}^{-3}$ (Table 1).

The Sf snowpack showed an increase in $\rho_{\mathrm{s}}$ variability and clearly distinguishable layers with greater $\rho_{\mathrm{s}}$ at 120 and
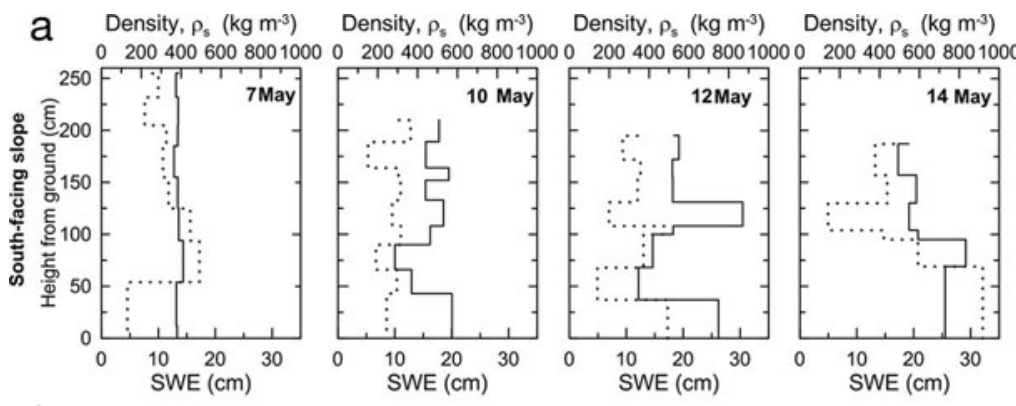

Density, $\rho_{\mathrm{s}}\left(\mathrm{kg} \mathrm{m}^{-3}\right) \quad$ Density, $\rho_{\mathrm{s}}\left(\mathrm{kg} \mathrm{m}^{-3}\right)$

Density, $\rho_{\mathrm{s}}\left(\mathrm{kg} \mathrm{m}^{-3}\right)$

Density, $\rho_{0}\left(\mathrm{~kg} \mathrm{~m}^{-3}\right)$

Density, $\left(\mathrm{kg} \mathrm{m}^{-3}\right)$
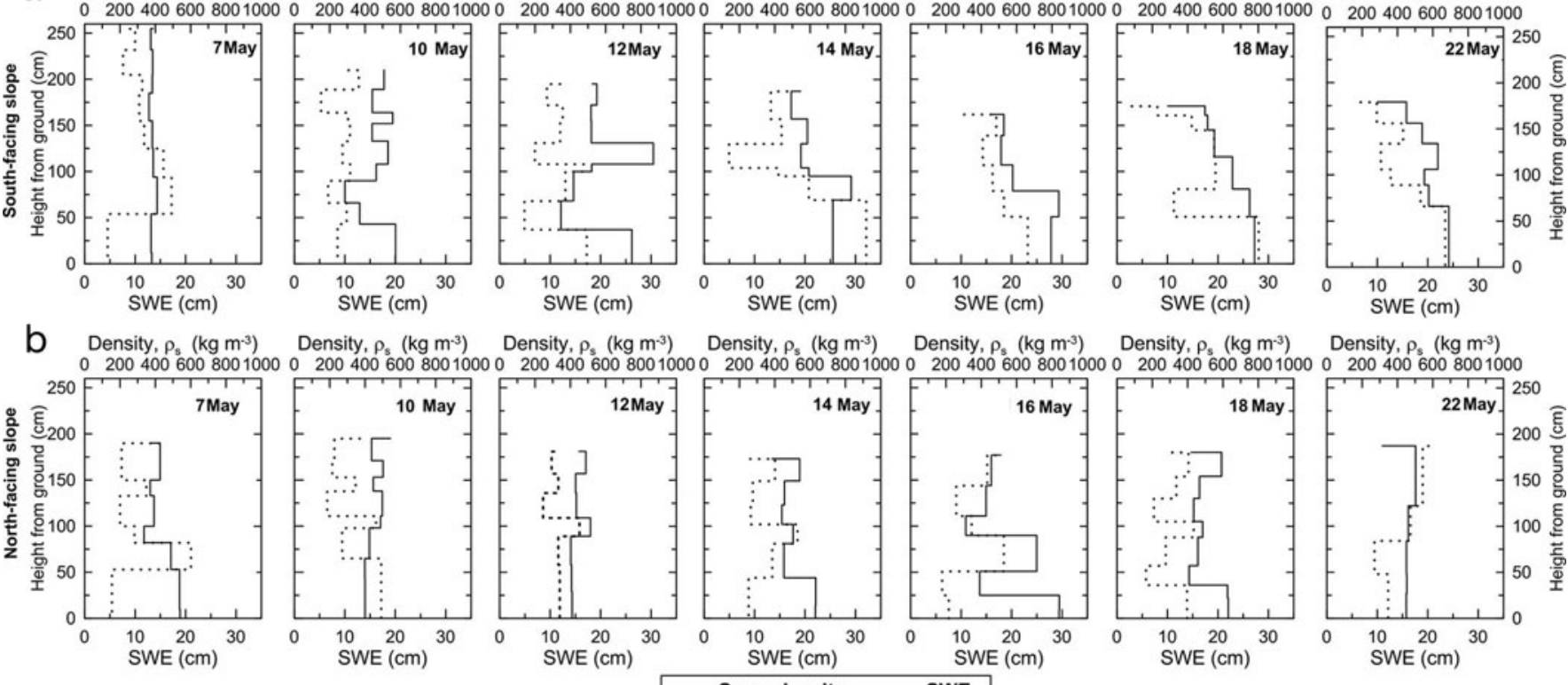

Fig. 3. Variability in snow density $\rho_{\mathrm{s}}$ and snow water equivalent (SWE) for two snowpacks located on (a) a south-facing (Sf) and (b) a northfacing (Nf) slope in the Tarfala catchment for seven dates in May 2011. 


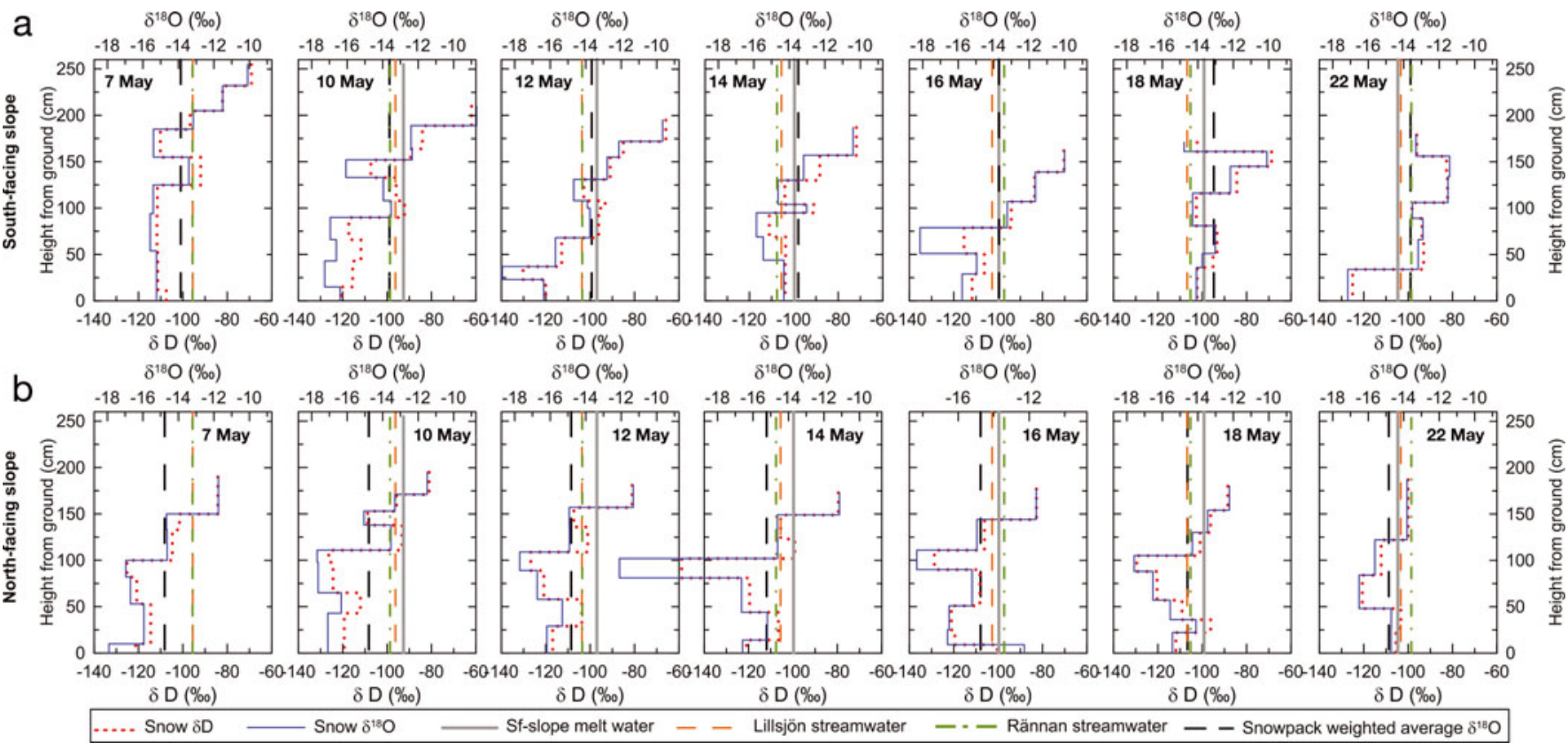

Fig. 4. Isotopic evolution of two snowpacks located on (a) a south-facing $(\mathrm{S} f$ ) and (b) a north-facing ( $\mathrm{Nf}$ ) slope in the Tarfala catchment for seven dates in May 2011. Step plots show the $\delta^{18} \mathrm{O}$ (blue solid line) and $\delta \mathrm{D}$ profiles (red dotted line). The vertical lines represent the meltwater $\delta^{18} \mathrm{O}$ collected at the base of the Sf slope (grey solid line), the streamwater $\delta^{18} \mathrm{O}$ collected at the Lillsjön gauging station (orange dashed line) and the catchment outlet Rännan (green dashed/dotted line) and the weighted average $\delta^{18} \mathrm{O}$ value of each snow profile (black dashed line).

$80 \mathrm{~cm}$ above ground during the period 7-14 May 2011. From 14 May 2011 onwards, however, the Sf snowpack showed a clear trend towards increasing $\rho_{\mathrm{s}}$ with depth (Fig. 3). The Sf snowpack showed a consistent decrease in snow depth from 255 to $162 \mathrm{~cm}$ and a corresponding increase in the average $\rho_{\mathrm{s}}$ from 383 to $618 \mathrm{~kg} \mathrm{~m}^{-3}$ until 16 May 2011 followed by a decrease in $\rho_{\mathrm{s}}$ to $552 \mathrm{~kg} \mathrm{~m}^{-3}$ and an increase in snow depth to $178 \mathrm{~cm}$ until the end of the study period. The increase in average $\rho_{\mathrm{s}}$ was partly due to formation of ice layers within the profile. Similarly, SWE increased from $97.9 \mathrm{~cm}$ at the beginning of the study period to $117.6 \mathrm{~cm}$ on 14 May 2011 and then decreased to $97.1 \mathrm{~cm}$ at the end of the study period. From 14 May 2011 onwards the snow at the base of the Sf snowpack (i.e. within $20 \mathrm{~cm}$ above ground) was saturated with meltwater as indicated by the high $\rho_{\mathrm{s}}$ values (Fig. 3).

In contrast, the $\mathrm{Nf}$ snowpack showed little increase in $\rho_{\mathrm{s}}$ variability over the entire study period, except on 16 May
2011 when the $\mathrm{Nf}$ snowpack reached its greatest average $\rho_{\mathrm{s}}$ of $0.52 \pm 0.19 \mathrm{~kg} \mathrm{~m}^{-3}$ and thus exhibited a clearly visible increase in $\rho_{\mathrm{s}}$ with depth into the snowpack (Table 1). This corresponds in time to the occurrence of the first precipitation event occurring during the study period (Fig. 2). The average snowpack $\rho_{\mathrm{s}}$ and SWE of the Nf snowpack showed no clear increasing or decreasing trends over the study period, with average values varying around $470 \pm 40 \mathrm{~kg} \mathrm{~m}^{-3}$ and $83 \pm 5 \mathrm{~cm}$, respectively. Over the study period the $\mathrm{Nf}$ snowpack did not show signs of saturation or capillary uptake at the base of the profile due to running meltwater (with the possible exception of the 16 May 2011 sampling). The Nf snowpack showed some signs of depth hoar at $\sim 100 \mathrm{~cm}$ above the base.

\section{Snowpack isotopic characteristics}

Figure 4 shows the $\delta^{18} \mathrm{O}$ and $\delta \mathrm{D}$ for the $\mathrm{Nf}$ and Sf snow profiles for seven dates between 7 and 22 May 2011. In

Table 1. Average snow density $\rho_{\mathrm{S}}( \pm 1 \mathrm{SD})$, snow water equivalent (SWE) and snow depth of two snowpacks located on a south-facing (Sf) and north-facing (Nf) slope in the Tarfala catchment for seven dates in May 2011

\begin{tabular}{|c|c|c|c|c|c|c|}
\hline \multirow[t]{3}{*}{ Sampling date } & \multicolumn{2}{|c|}{ Density } & \multicolumn{2}{|c|}{ SWE } & \multicolumn{2}{|c|}{ Snow depth } \\
\hline & Sf slope & Nf slope & Sf slope & Nf slope & Sf slope & Nf slope \\
\hline & $\mathrm{kg} \mathrm{m}^{-3}$ & $\mathrm{~kg} \mathrm{~m}^{-3}$ & $\mathrm{~cm}$ & $\mathrm{~cm}$ & $\mathrm{~cm}$ & $\mathrm{~cm}$ \\
\hline 7 May & $383 \pm 13$ & $418 \pm 72$ & 97.9 & 77.7 & 255 & 190 \\
\hline 10 May & $458 \pm 88$ & $468 \pm 48$ & 96.5 & 89.9 & 210 & 195 \\
\hline 14 May & $618 \pm 120$ & $487 \pm 81$ & 117.6 & 82.9 & 187 & 173 \\
\hline 16 May & $618 \pm 160$ & $522 \pm 189$ & 99.7 & 85.4 & 162 & 177 \\
\hline 18 May & $576 \pm 169$ & $486 \pm 80$ & 103.8 & 88.6 & 171 & 180 \\
\hline 22 May & $552 \pm 134$ & $436 \pm 72$ & 97.1 & 77.3 & 178 & 187 \\
\hline
\end{tabular}


Table 2. Statistical summary of the $\delta^{18} \mathrm{O}$ isotopic composition of the two snow profiles (Sf slope and Nf slope) (weighted averages), the meltwater collected at the base of the Sf slope, and streamwater collected at the Lillsjön gauging station and the catchment outlet (Rännan)

\begin{tabular}{|c|c|c|c|c|c|}
\hline Sampling date & $\begin{array}{c}\text { Sf slope } \\
\% \text { o }\end{array}$ & $\begin{array}{c}\text { Nf slope } \\
\% \text { o }\end{array}$ & $\begin{array}{c}\text { Sf slope meltwater } \\
\% \text { \% }\end{array}$ & $\begin{array}{c}\text { Lillsjön streamwater } \\
\% 0\end{array}$ & $\begin{array}{c}\text { Rännan streamwater } \\
\% \text { \% }\end{array}$ \\
\hline 7 May & $-14.1 \pm 2.0$ & $-15.2 \pm 1.9$ & n.a. & -13.0 & -13.0 \\
\hline 10 May & $-14.4 \pm 2.8$ & $-15.4 \pm 2.3$ & -13.3 & -13.4 & -14.0 \\
\hline 12 May & $-14.1 \pm 2.6$ & $-15.3 \pm 2.0$ & -13.6 & -14.4 & -14.2 \\
\hline 14 May & $-14.0 \pm 1.8$ & $-16.0 \pm 3.8$ & -13.5 & -14.7 & -15.0 \\
\hline 16 May & $-14.3 \pm 2.9$ & $-14.9 \pm 2.4$ & -13.9 & -13.8 & -14.0 \\
\hline 18 May & $-13.3 \pm 1.6$ & $-14.9 \pm 1.7$ & -13.4 & -14.5 & -14.4 \\
\hline 22 May & $-13.7 \pm 1.9$ & $-14.9 \pm 1.0$ & -14.3 & -14.1 & -14.0 \\
\hline
\end{tabular}

n.a.: not available.

Figure 4 the lines represent the meltwater $\delta^{18} \mathrm{O}$ collected at the base of the Sf slope, the streamwater $\delta^{18} \mathrm{O}$ collected at the Lillsjön gauging station and the catchment outlet (Rännan) and the weighted average $\delta^{18} \mathrm{O}$ value of each snow profile. Table 2 lists the weighted mean $\delta^{18} \mathrm{O}$ values for each sampling date of both the Nf and Sf snowpack, the isotopic composition of the meltwater collected at the base of the Sf slope and the streamwater collected at the Lillsjön gauging station and the catchment outlet. The total population of $\delta^{18} \mathrm{O}$ and $\delta \mathrm{D}$ values observed in the $\mathrm{Sf}$ snowpack was significantly different $(p<0.01$, two-sided $t$ test at a significance level of $1 \%$ ) from the isotope values observed in the $\mathrm{Nf}$ snowpack. The $\delta^{18} \mathrm{O}$ values within the Sf snowpack were generally more enriched, and varied between $-18.7 \%$ and $-8.7 \%$ over the study period, with a mean value of $-13.8 \pm 2.2 \%$ o (Table 2). In contrast, the $\mathrm{Nf}$ snowpack showed consistently more depleted values and varied between $-23.5 \%$ and $-11.1 \%$, with a mean of $-15.3 \pm 2.2 \%$ (Table 2 ). Over the entire study period, the Sf snowpack showed a consistently larger range of isotopic values than the $\mathrm{Nf}$ snowpack, potentially indicating more pronounced isotopic redistribution (Fig. 4).

Although the distribution of isotope values within each snowpack showed a characteristic decrease from the top to the bottom of the snowpack profile, comparison of the isotopic composition between the $\mathrm{Nf}$ and Sf snowpack (and their respective evolution over time) highlights several main differences. As illustrated in Figure 4, the decrease in isotope values with depth into the snowpack was more pronounced in the $\mathrm{Sf}$ snowpack than in the Nf snowpack. There was a clear difference in the depth over which the decrease in isotope values occurred, with a greater range of decrease into the $\mathrm{Sf}$ snowpack than into the $\mathrm{Nf}$ snowpack (Fig. 4). Also, prior to the first precipitation event occurring on 16 May 2011, the snow at the surface of the Sf snowpack exhibited isotopic compositions between about $-10 \%$ and $-8 \%$ for $\delta^{18} \mathrm{O}$. Counter to this, the surface of the $\mathrm{Nf}$ snowpack was consistently about $2-3 \%$ more negative for $\delta^{18} \mathrm{O}$. This indicates that the top the Sf snowpack was isotopically more enriched relative to the top of the $\mathrm{Nf}$ snowpack during the period before the precipitation event on 16 May 2011. This is also supported as the isotopically depleted new snow (e.g. on 16-17 May 2011 with $\delta^{18} \mathrm{O}=-17.2 \%$ ) became heavier $\left(\delta^{18} \mathrm{O}=-13.3 \%\right.$ ) within just 5 days after deposition for the $\mathrm{Sf}$ slope, while not much change was seen for the $\mathrm{Nf}$ slope after this precipitation event (Fig. 4).
Over the course of the study period the weighted mean $\delta^{18} \mathrm{O}$ value of both snowpacks became isotopically heavier (Table 2). The Sf snowpack showed clear signs of isotopic redistribution within the snowpack via percolating meltwater and isotopic enrichment at the base of the snowpack due to loss of isotopically lighter meltwater as lateral runoff. Counter to this, the $\mathrm{Nf}$ snowpack showed mean weighted isotope values that were $\sim 0.6-2.0 \%$ more negative than the values observed in the Sf snowpack. Over the course of the study period, however, the mean weighted isotopic composition of the $\mathrm{Nf}$ snowpack (and particularly that of the base of the $\mathrm{Nf}$ snowpack) approached the mean weighted isotopic composition observed in the Sf snowpack.

At the beginning of the study period, the isotopic composition of streamwater collected at the Lillsjön gauging station was less depleted than the $\delta^{18} \mathrm{O}$ values observed at the base of either the $\mathrm{Nf}$ and $\mathrm{Sf}$ snowpack or the weighted mean $\delta^{18} \mathrm{O}$ values for either snowpack. Over the study period, however, the streamwater isotopic composition at Lillsjön and at the catchment outlet became more similar to the isotopic composition of the Sf snowpack base. Towards the end of the study period the Sf snowpack weighted mean $\delta^{18} \mathrm{O}$ value was isotopically more enriched than the streamwater isotopic composition collected at either Lillsjön or the catchment outlet. In contrast, the weighted mean $\delta^{18} \mathrm{O}$ values of the $\mathrm{Nf}$ snowpack were consistently lower than the isotopic composition of the streamwater collected at Lillsjön and the catchment outlet. Based on three streamwater samples collected in January and mid-March, when discharge was lowest and presumably dominated by groundwater-derived base flow, a median isotopic value of $-13.66 \%$ was observed (Dahlke and others, 2013). A comparison of the mean weighted $\delta^{18} \mathrm{O}$ values of either snowpack with the streamwater isotopic composition suggests that snowmelt contributions were small at the beginning and increased towards the end of the study period (Table 2).

\section{Developing a conceptual framework for early-period snowmelt}

There was a clear enrichment in stable water isotopes in both snowpacks moving towards the surface of the snowpacks (Fig. 4). Similar to other studies this isotopic enrichment can be attributed largely to isotopic redistribution and fractionation of water isotopes in the surface layers of the snowpacks due to evaporation or sublimation and percolation of isotopically lighter meltwater into the 
snowpack (e.g. Colbeck, 1978; Moser and Stichler, 1980; Taylor and others, 2001, 2002; Feng and others, 2002; Zhou and others, 2008). Isotopic enrichment due to these processes was particularly visible in the Sf snowpack where isotopically depleted new snow became enriched in heavy isotopes by $>4 \%$ within 5 days. Since both snowpacks were located at the same elevation in close proximity to each other, the observed increase in ${ }^{18} \mathrm{O}$ cannot result from altitudinal or temporal variation in the precipitation isotopic composition. In addition, similar to the findings of Moser and Stichler (1980) both snowpacks formed a distinct natural profile of isotopic composition that was maintained during the onset of the pre-freshet melt in this system. The snowpacks on the Sf and Nf slopes, however, showed a statistically significant difference in their mean weighted isotopic composition, indicating temporal differences in the degree to which isotopic fractionation due to meltingfreezing mass exchange occurred. As such, there were spatio-temporal differences in the contribution of meltwater to streams within Tarfala valley over this period. The influence of these differences can be seen in the resulting streamwater isotopic composition (Fig. 4; Table 2).

The comparison of snowpacks and their isotopic profiles on slopes with opposing aspects can feed into the development of a conceptualization of the early-period snowmelt at Tarfala valley. During early melt periods when the average daily temperature is still low, melting occurs primarily on sun-exposed slopes as these slopes receive the largest influx of solar radiation. For the Tarfala valley and other northern-latitude systems with steep topography, these areas correspond to southern-facing slopes. Further, since the angle of the sun is still low during the pre-freshet periods, isotopic redistribution and fractionation within a snowpack and meltwater formation occur predominately on Sf slopes with greater slope angles and thus greater insolation. In the present study, this corresponds to the upslope areas of the $\mathrm{Sf}$ slope. As this meltwater makes its way downslope towards the stream, it flows largely at the ground-surface-snowpack interface due to the typically frozen subsurface conditions. This concentrated lateral flux of isotopically enriched meltwater mixes with meltwater generated in situ that has percolated through the snow column of downslope snowpacks. Eventually, this mixed snowmelt water is contributed to the stream only if the concentrated lateral meltwater flux from Sf upslope areas connects to the stream via, for example, preferential flow pathways. As the freshet period progresses, meltwater production from Sf upslope areas will increase and expand downslope to areas with smaller slope angles (e.g. footslopes) and longitudinally across slopes (e.g. to slopes with more southeasterly and southwesterly aspects), resulting in a progressive contribution of isotopically enriched meltwater from a relatively small but actively melting portion of the catchment.

Counter to this, $\mathrm{Nf}$ slopes remain largely shadowed throughout the freshet period due to the low angle of the sun. Thus, the $\mathrm{Nf}$ snowpack primarily sees a metamorphic and isotopic evolution of the snowpack without large meltwater generation during the same periods when the $\mathrm{Sf}$ slopes are actively melting. However, the $\mathrm{Nf}$ snowpack contributes isotopically enriched meltwater towards the end of the freshet period when snowpacks in Sf positions have melted away. This is seen in the Nf slope in this study, which experiences little change in SWE and snow density over the period considered. Rather, there is isotopic fractionation and redistribution in its profile due to melting-freezing mass exchange (Zhou and others, 2008) that causes enrichment in the mean weighted isotopic composition of the snowpack such that it approaches isotopic values similar to those observed in the Sf snowpack.

This simple conceptualization is confirmed by observations at the catchment outlet and supports the applicability of a distributed snowmelt source area model for the Tarfala catchment. In this study the isotopic composition of the streamwater, which integrates meltwater from both the $\mathrm{Nf}$ slope (contributing little) and Sf slope (contributing much) during the period of observation, follows the isotopic composition seen at the base of the Sf slope. Consistent with the previous conceptualization, this isotopic composition at the base of the Sf slope is similar to, and controlled by, the vertical flux of isotopically enriched meltwater through the snow column and the lateral flux of snow meltwater from Sf upslope areas. This indicates that the water going into the stream during this early melt season period comes predominantly from southern-facing slopes and looks isotopically like a mixture of meltwater percolating through snow column and meltwater from upslope areas flowing at the ground-surface-snowpack interface. At the catchment scale, this potentially means that the source and amount of meltwater contributed to streams during the prefreshet (and potentially the freshet) period can be represented by three fundamental groups of processes: (1) processes controlling the mass balance and isotopic evolution of an individual snowpack (i.e. energy balance); (2) processes controlling the flow pathways by which meltwater is transported at the ground-surface-snowpack interface from melting areas to streams (e.g. topography); and (3) processes controlling the expansion of meltwaterproducing areas over time. Processes in (1) are well conceptualized, for example by one-dimensional models that simulate the isotopic composition of meltwater exiting the base of a snowpack (e.g. Jordan, 1991; Taylor and others, 2001, 2002; Feng and others, 2002) or by distributed energybalance-based melt models such as Alpine3D (Lehning and others, 2006). However, the accuracy of distributed energybalance snowmelt models in predicting snowmelt source areas across a landscape does not necessarily match the accuracy that these models achieve when simulating the timing and magnitude of the ionic pulse. Based on the conceptual understanding of spatio-temporal snowmelt processes in the Tarfala catchment gained from this isotope study, we believe that distributed snowmelt models can be improved by coupling the existing energy-balance approaches with the topography-based partial area concepts (e.g. Engman and Rogowski, 1974; Dahlke and others, 2009) of runoff generation. This concept, which could be realized in a GIS-based modelling framework, would allow the more accurate identification of snowmelt hotspots (i.e. Sf slopes with high insulation) and their spatial expansion over time, while at the same time allowing for a more realistic routing of the concentrated lateral flux of meltwater to streams via, for example, a topographic index approach (Beven and Kirkby, 1979; Lyon and others, 2004).

\section{CONCLUDING REMARKS}

This study presents an investigation of the isotopic variability and evolution for the snowpack of two distinct slopes, a north- and a south-facing slope, within the Tarfala 
catchment. Aspect was found to be a strong control on the pre-freshet snowpack isotopic evolution and early season meltwater generation. The investigation could be incorporated into the development of a conceptual framework of spatio-temporal snowmelt dynamics. Such a conceptualization is a first step towards the development of an improved understanding of spatio-temporal snowmelt processes and their conceptualization in distributed snowmelt models. This is relevant for the estimation of snowmelt contributions to streamflow and identification of snowmelt source areas within the Tarfala catchment and (potentially) other highlatitude high-altitude landscapes.

\section{ACKNOWLEDGEMENTS}

We thank Torbjörn Karlin for his assistance in the field and the Swedish Society for Anthropology and Geography for funding. We also thank Tarfala research station for invaluable logistical support and the Delta Facility of Stockholm University for the isotope analysis.

\section{REFERENCES}

Bales RC, Davis RE and Stanley DE (1989) Ion elution through shallow homogeneous snow. Water Resour. Res., 25(8), 1869-1877 (doi: 10.1029/WR025i008p01869)

Beven KJ and Kirkby MJ (1979) A physically based, variable contributing area model of basin hydrology. Hydrol. Sci. Bull., 24(1), 43-69 (doi: 10.1080/02626667909491834)

Broxton PD, Troch PA and Lyon SW (2009) On the role of aspect to quantify water transit times in small mountainous catchments. Water Resour. Res., 45(W8), W08427 (doi: 10.1029/ 2008WR007438)

Colbeck SC (1978) The physical aspects of water flow through snow. In Chow VT ed. Advances in Hydroscience, Vol. 11. Academic Press, New York, 165-206

Cragin JH, Hewitt AD and Colbeck SC (1996) Grain-scale mechanisms influencing the elution of ions from snow. Atmos. Environ., 30(1), 119-127 (doi: 10.1016/1352-2310(95)00232-N)

Dahlke HE, Easton ZM, Fuka DR, Lyon SW and Steenhuis TS (2009) Modelling variable source area dynamics in a CEAP watershed. Ecohydrology, 2(3), 337-349 (doi: 10.1002/eco.58)

Dahlke HE, Lyon SW, Stedinger JR, Rosqvist G and Jansson P (2012) Contrasting trends in floods for two sub-arctic catchments in northern Sweden - does glacier presence matter? Hydrol. Earth Syst. Sci., 16(7), 2123-2141 (doi: 10.5194/hess-16-2123-2012)

Dahlke HE, Lyon SW, Jansson P, Karlin T and Rosqvist G (2013) Isotopic investigation of runoff generation in a glacierized catchment in northern Sweden. Hydrol. Process. (doi: 10.1002/ hyp.9668)

Engman ET and Rogowski AS (1974) A partial area model for storm flow synthesis. Water Resour. Res., 10(3), 464-472

Feng X, Taylor S, Renshaw CE and Kirchner JW (2002) Isotopic evolution of snowmelt 1 . A physically based one-dimensional model. Water Resour. Res., 38(10), 1217 (doi: 10.1029/ 2001WR000814)

Gustafson JR, Brooks PD, Molotch NP and Veatch WC (2010) Estimating snow sublimation using natural chemical and isotopic tracers across a gradient of solar radiation. Water Resour. Res., 46(W12), W12511 (doi: 10.1029/2009WR009060)

Harrington R and Bales RC (1998) Modeling ionic solute transport in melting snow. Water Resour. Res., 34(7), 1727-1736 (doi: 10.1029/98WR00557)

Holmlund P, Jansson P and Pettersson R (2005) A re-analysis of the 58 year mass-balance record of Storglaciären, Sweden. Ann. Glaciol., 42, 389-394 (doi: 10.3189/172756405781812547)

Hrachowitz M, Soulsby C, Tetzlaff D, Malcolm IA and Schoups G (2010) Gamma distribution models for transit time estimation in catchments: physical interpretation of parameters and implications for time-variant transit time assessment. Water Resour. Res., 46(W10), W10536 (doi: 10.1029/2010WR009148)

Jordan R (1991) A one-dimensional temperature model for a snow cover: technical documentation for SNTHERM.89. CRREL Spec. Rep. 91-16.

Kattelmann R and Elder K (1991) Hydrologic characteristics and water balance of an Alpine Basin in the Sierra Nevada. Water Resour. Res., 27(7), 1553-1562 (doi: 10.1029/90WR02771)

Lee J and 6 others (2010) Isotopic evolution of a seasonal snowcover and its melt by isotopic exchange between liquid water and ice. Chemical Geol., 270(1-4), 126-134 (doi: 10.1016/ j.chemgeo.2009.11.011)

Lehning M, Völksch I, Gustafsson D, Nguyen TA, Stähli M and Zappa M (2006) ALPINE3D: a detailed model of mountain surface processes and its application to snow hydrology. Hydrol. Process., 20(10), 2111-2128 (doi: 10.1002/hyp.6204)

Liu F, Bales RC, Conklin MH and Conrad ME (2008) Streamflow generation from snowmelt in semi-arid, seasonally snow-covered, forested catchments, Valles Caldera, New Mexico. Water Resour. Res., 44(W12), W12443 (doi: 10.1029/2007WR006728)

López-Moreno JI and Latron J (2008) Spatial heterogeneity in snow water equivalent induced by forest canopy in a mixed beech-fir stand in the Pyrenees. Ann. Glaciol., 49, 83-90 (doi: 10.3189/ 172756408787814951)

Lyon SW, Walter MT, Gérard-Marchant P and Steenhuis TS (2004) Using a topographic index to distribute variable source area runoff predicted with the SCS curve-number equation. Hydrol. Process., 18(15), 2757-2771 (doi: 10.1002/hyp.1494)

Lyon SW, Desilets SLE and Troch PA (2009) A tale of two isotopes: differences in hydrograph separation for a runoff event when using $\delta \mathrm{D}$ versus $\delta^{18} \mathrm{O}$. Hydrol. Process., 23(14), 2095-2101 (doi: 10.1002/hyp.7326)

Lyon SW, Laudon H, Seibert J, Mörth M, Tetzlaff D and Bishop KH (2010) Controls on snowmelt water mean transit times in northern boreal catchments. Hydrol. Process., 24(12), 1672-1684 (doi: 10.1002/hyp.7577)

Marsh CB, Pomeroy JW and Spiteri RJ (2012) Implications of mountain shading on calculating energy for snowmelt using unstructured triangular meshes. Hydrol. Process., 26(12), 1767-1778 (doi: 10.1002/hyp.9329)

McDonnell JJ and 27 others (2010) How old is streamwater? Open questions in catchment transit time conceptualization, modelling and analysis. Hydrol. Process., 24(12), 1745-1754 (doi: 10.1002/hyp.7796)

Monson RK and 6 others (2006) Winter forest soil respiration controlled by climate and microbial community composition. Nature, 439(7077), 711-714 (doi: 10.1038/nature04555)

Moser H and Stichler W (1980) Environmental isotopes in ice and snow. In Fritz P and Fonte JC eds. Handbook of environmental isotope geochemistry. Elsevier, Amsterdam, 141-178

Murphy EM and Ginn TR (2000) Modeling microbial processes in porous media. Hydrogeol. J., 8(1), 142-158 (doi: 10.1007/ s100409900043)

Pomeroy JW, Toth B, Granger RJ, Hedstrom NR and Essery RLH (2003) Variation in surface energetics during snowmelt in a subarctic mountain catchment. J. Hydromet., 4(4), 702-719 (doi: 10.1175/1525-7541(2003)004<0702:VISEDS>2.0.CO;2)

Pomeroy JW, Jones HG, Tranter M and Lilbæk G (2005) Hydrochemical processes in snow-covered basins. In Anderson MG and McDonnell JJ eds. Encyclopedia of hydrological sciences, Vol. 4. Wiley, New York, 2525-2588

Rodhe A (1998) Snowmelt-dominated systems. In Kendall C and McDonnell JJ eds. Isotope tracers in catchment hydrology. Elsevier, Amsterdam, 391-434

Scanlon TM, Raffensperger JP and Hornberger GM (2001) Modeling transport of dissolved silica in a forested headwater catchment: implications for defining the hydrochemical response of observed flow pathways. Water Resour. Res., 37(4), 1071-1082 (doi: 10.1029/2000WR900278) 
Taylor S, Feng X, Kirchner JW, Osterhuber R, Klaue B and Renshaw CC (2001) Isotopic evolution of a seasonal snowpack and its melt. Water Resour. Res., 37(3), 759-769 (doi: 10.1029/ 2000WR900341)

Taylor S, Feng X, Williams M and McNamara J (2002) How isotopic fractionation of snowmelt affects hydrograph separation. Hydrol. Process., 16(18), 3683-3690 (doi: 10.1002/hyp.1232)

Unnikrishna PV, McDonnell JJ and Kendall CC (2002) Isotope variations in a Sierra Nevada snowpack and their relation to meltwater. J. Hydrol., 260(1), 38-57 (doi: 10.1016/S0022-1694 (01)00596-0)

Veatch W, Brooks PD, Gustafson JR and Molotch NP (2009) Quantifying the effects of forest canopy cover on net snow accumulation at a continental, mid-latitude site. Ecohydrology, 2(2), 115-128 (doi: 10.1002/eco.45)

Zhou S, Nakawo M, Hashimoto S and Sakai A (2008) The effect of refreezing on the isotopic composition of melting snowpack. Hydrol. Process., 22(6), 873-882 (doi: 10.1002/hyp.6662) 